\title{
Three Favorite Results
}

\author{
Jennifer Widom \\ Stanford University, Stanford, CA, USA \\ widom@stanford.edu
}

\begin{abstract}
Being honored as the ACM Athena Lecturer has inspired me to reflect upon the research I've conducted over my career to date. Conventional wisdom says good things come in threes, so I've picked three of my favorite results to cover during the talk. For each one I'll explain the context and motivation, the result itself, and why it ranks as one of my favorites. The three results span foundations, implementation, and userinterface, and they represent three of my favorite research areas: semistructured data, data streams, and uncertain data.
\end{abstract}

\section{ACM Classification}

H.2 Database Management

Keywords

Semistructured data; data streams; uncertain data

Permission to make digital or hard copies of part or all of this work for personal or classroom use is granted without fee provided that copies are not made or distributed for profit or commercial advantage, and that copies bear this notice and the full citation on the first page. Copyrights for third-party components of this work must be honored. For all other uses, contact the owner/author(s). Copyright is held by the author/owner(s).

SIGMOD'15, May 31-June 4, 2015, Melbourne, Victoria, Australia.

ACM 978-1-4503-2758-9/15/05.

http://dx.doi.org/10.1145/2723372.2753770 